\title{
ORGANIZATION OF INDEPENDENT COGNITIVE ACTIVITY OF STUDENTS IN FOREIGN LANGUAGE CLASSES
}

\section{ОРГАНІЗАЦІЯ САМОСТІЙНОЇ ПІЗНАВАЛЬНОЇ ДІЯЛЬНОСТІ СТУДЕНТІВ НА ЗАНЯТТЯХ 3 ІНОЗЕМНОЇ МОВИ}

\section{Svitlana Zaskalieta ${ }^{1}$}

DOI: https://doi.org/10.30525/978-9934-26-069-8-5

Abstract. The purpose of this article is to analyze the domestic and European experience in organizing the cognitive activity of students in foreign language classes, to identify its main ways of activation. The main direction of development of modern humanitarian education in Ukraine is to increase the level of higher education to European. Entering the European educational space. Ensuring the quality of education, modernization of its content, development and implementation of educational innovations and information technologies, creating conditions for training a specialist suitable for effective implementation of innovative tasks of the appropriate level of professional activity is an urgent task facing higher education institutions. One of the priority areas of education reform is the need to achieve a qualitatively new level in the study of foreign languages. Unlike other subjects, a foreign language is a whole field of knowledge, as it reveals to a person the treasury of a foreign language culture, new lifestyles. Ukraine's integration into the world community requires perfect command of foreign languages. The article highlights the current problems of modernization of higher education and identifying ways to enhance the independent cognitive activity of students in foreign language classes. Particular attention is paid to the characteristics of the most effective methods of teaching English in higher education. As a result of theoretical analysis and experience of work of university teachers on new educational and methodical complexes the aspects which remained out of attention of scientific researches are revealed. These include the methodological potential

\footnotetext{
${ }^{1}$ Doctor of Sciense (Pedagogy),

Professor of English Language and Literature Department,

V.O. Sukhomlynskyi Mykolaiv National University, Ukraine
}

(C) Svitlana Zaskalieta 
of the organization of independent cognitive activity of students, as well as the use of interdisciplinary links in foreign language classes. The realization of this idea is impossible without the development and implementation of appropriate learning technologies. Among the approaches, the author singles out the introduction of an interdisciplinary approach.

\section{1. Ветуп}

Сьогодні у відповідь на сучасні виклики (трансформація суспільств, скорочення фінансування освіти) світова освітня спільнота вирішує проблему забезпечення якості вищої освіти. Якість освіти - не національна, а глобальна проблема. За визначенням ЮНЕСКО, XXI століття є століттям якісної освіти.

Тому сучасна освіта вимагає розробки та впровадження нових освітніх технологій, здатних забезпечити високу якість професійної підготовки фахівців. Виконання цього завдання $є$ особливо актуальною проблемою для вітчизняної освіти, яка сьогодні реформується.

Національна доктрина розвитку освіти визначає систему концептуальних ідей та поглядів на стратегію і основні напрями розвитку освіти у першій чверті XXI століття. Серед пріоритетів державної політики в розвитку освіти $\epsilon[10]$ :

- особистісна орієнтація освіти;

- формування національних та загальнолюдських цінностей;

- створення рівних можливостей для дітей і молоді у здобутті якісної освіти, постійного оновлення змісту освіти;

- інтеграцію української освіти у європейський та світовий освітній простір.

Щодо міжнародного співробітництва у галузі освіти, то Національна доктрина розвитку освіти зазначає, що стратегічним завданням державної політики є вихід освіти, набутої в Україні, на ринок світових освітніх послуг, поглиблення міжнародного співробітництва, розширення участі навчальних закладів, учених, педагогів і вчителів, учнів, студентів у проектах міжнародних організацій та співтовариств. Ось чому актуалізується питання розробки та впровадження інноваційних методів навчання у закладах вищої освіти України.

Метою цієї статті $є$ вивчення суті поняття визначення особливостей використання основних інноваційних методів у практичній діяльно- 
сті викладача іноземної мови, з'ясування значення таких методів для сучасної вищої школи України.

\section{2. Аналіз останніх досліджень і публікацій}

Національна доктрина розвитку освіти визначає, що стратегічною метою модернізації мовної освіти є обов'язкове оволодіння громадянами України державною мовою, можливість опановувати рідну (національну) і практично володіти хоча б однією іноземною мовою [12].

Отже, перехід до інноваційної освіти, зокрема у вищій школі, зумовлена викликами сьогодення і належить до пріоритетних напрямів державної політики в Україні у контексті інтеграції вітчизняної освітньої галузі до європейського та світового освітнього простору. А відтак, забезпечення якості освіти, модернізації іiі змісту, розробка й упровадження освітніх інновацій та інформаційних технологій, створення умов для підготовки фахівця, придатного «для ефективного виконання завдань інноваційного характеру відповідного рівня професійної діяльності» є актуальним завданням, що постає перед закладами вищої освіти [4].

Серед основних шляхів реформування освіти визначено такі:

- забезпечення розвитку освіти на основі нових прогресивних концепцій;

- запровадження у навчально-виховний процес сучасних педагогічних технологій та науково-методичних досягнень [1].

Головним напрямом розвитку сучасної гуманітарної освіти України $€$ підвищення рівня вітчизняного навчання до європейського. Тобто входження в загальноєвропейський освітній простір.

Як зазначається у Державній національній програмі «Освіта. Україна XXI сторіччя», одним із пріоритетних напрямів реформування освіти, $є$ необхідність «досягнення якісно нового рівня у вивченні іноземних мов» [1]. Отже, Інтеграція України у світову спільноту потребує досконалого володіння іноземними мовами.

Крім традиційних вимог до якості вищої освіти (отримання якісного диплома і високої професійної компетентності тощо), постали такі: спроможність оперувати сучасними інформаційно-комунікаційними засобами, вміння займатися самонавчанням для збереження конкретного місця праці й кар'єрного зростання на ньому, володіння 
лідерськими якостями, готовність до колективної діяльності та до вимушеної зміни професії у зв'язку з появою технологічних [2]. Ось чому виникає необхідність пошуку нових шляхів щодо розвитку філологічної освіти в контексті інтеграції в європейський освітній простір.

Аналіз наукових робіт свідчить про те, що не було видано узагальнюючої праці з аналізу тенденцій професійної підготовки фахівців. Однак, окремі іiі аспекти висвітлено у наукових дослідженнях, які умовно можна поділити на три групи:

1) дослідження з філософії освіти (В.П. Андрущенко, І.А. Зязюн, В.Г. Кремень, В.О. Огнев'юк, П.Ю. Саух);

2) узагальнюючі праці 3 усього комплексу проблем професійної підготовки фахівців в Україні (С.У. Гончаренко, Т.М. Десятов, А.А. Сбруєва, В.І. Луговий, Н.Г. Ничкало, С.О. Сисоєва);

3) наукові праці, в яких розглядаються проблеми професійної підготовки фахівців в країнах СС (Н.В. Абашкіна, А.Г. Андрощук, Н. Батечко, Л.В. Козак, Т. Кристопчук, Л.П. Пуховська, І.В. Соколова та інші).

Аналіз проблеми модернізації освіти в контексті інноваційних тенденцій розвитку суспільства проаналізовано у роботах В.Г. Кременя. Вчений зазначає, що сучасна освіта та професійна підготовка фахівців повинна відповідати на нові виклики сучасності. В.Г. Кремень наголошує, що найважливішими пріоритетами життєдіяльності будьякого суспільства є формування суспільства знань [9]. В.Г. Кремень також зазначає, що освітньо-педагогічні зміни в національному масштабі відбуваються в контексті загально цивілізованих трансформацій, зумовлених широким розповсюдженням нових освітніх технологій, заснованих на використанні можливостей і потреб в індивідуальному особистому розвитку людини. Аналізуючи проблему модернізації освіти в контексті інноваційних тенденцій розвитку суспільства, вчений вказує, що подальший прогрес цивілізації, яка у XXI ст. є прото-глобальною, пов'язаний з інноваціями, необхідністю формування інноваційної людини з новим інноваційним типом мислення.

На необхідність дослідження сфери освіти у ії сталому розвитку підкреслює В.О. Огнев'юк [10]. За його концепцією, освітологія як науковий напрям інтегрованого пізнання освіти найбільш повно відображає всі знання, що стосуються освіти. Тому, на нашу думку, профе- 
сійну підготовку фахівців потрібно розглядати під кутом зору концепції освіти упродовж життя.

П.Ю. Саух, вважає, що роль освіти в суспільстві полягає не лише в ретрансляції знань і соціального досвіду з покоління в покоління, але й у тому, щоб готувати людину до діяльності в умовах біфуркацій й невизначеності, до вміння виходити із різноманітних глобальних криз та катастроф, долати які можна не застарілими, а лише випереджаючими знаннями і системними діями.

У своїх дослідженнях Маріанна Кляп [8, с. 45-43] наголошує на пріоритетності створення інноваційного освітнього середовища у вищих навчальних закладах через сприяння прогресивним нововведенням, а саме:

- впровадження інноваційних методів навчання;

- застосування широкого діапазону новітніх методів навчання стане однією з ознак інноваційних університетів і започаткує процес інтернаціоналізації вищої школи України;

- кожний вищий навчальний заклад створює свою базу найбільш часто використовуваних інноваційних методів з урахуванням специфіки викладацького складу, контингенту студентів, особливостей спеціальностей, фахівців, яких готує конкретний виш, матеріально-технічного забезпечення та ін. У результаті теоретичного аналізу і досвіду роботи викладачів університетів за новими навчально-методичними комплексами (2015-2020рр.) виявлено аспекти, які залишалися поза увагою наукових пошуків, хоча важливість їх зазначено у чинних програмах. До них ми зараховуємо потенціал самостійної пізнавальної діяльності студентів, а також застосування міжпредметних зв'язків на заняттях з іноземної мови.

\section{3. Організація самостійної пізнавальної діяльності студентів} на заняттях $з$ іноземної мови

Аналіз ефективності організації самостійної навчально-пізнавальної діяльності студентів на заняттях з іноземної мови, дає підстави констатувати, що традиційні методи навчання не дають задовільних результатів і не завжди стимулюють самостійність, активність і творчість. У процесі аналізу джерел серед інших показників визначалась частота постановки питань про [6]: 
- необхідність удосконалення організації самостійної пізнавальної діяльності студентів;

- посилення творчого компоненту навчального процесу;

- розширення тематики та підвищення якості науково-дослідної роботи студентів;

- переведення студентів на індивідуальний навчальний план;

- виявлення талановитих студентів;

- удосконалення організації, управління, контролю і оцінки самостійної роботи студентів.

Самостійна пізнавальна діяльність студентів активізується у процесі вивчення навчальних дисциплін. Однак сформованість знань, умінь та навичок з предмета, що вивчається як самостійний компонент пізнавальної діяльності, визначено відносно недавно. Сфера реалізації пізнавальної активності - навчальна діяльність на занятті з певного предмету, у процесі викладання якого педагог її формує.

В основі організації самостійної пізнавальної діяльності студентів на заняттях з іноземної мови лежить система мотивів. Ця система виходить із пізнавальної потреби. Остання - це суб'єктивне відображення об'єктивної потреби суспільства в знаннях, потреби людини у функціонуванні тих сторін психіки, завдяки яким відбувається пізнання [6].

Потреба в знаннях, в пізнанні дійсності, яка оточує - є однією 3 основних духовних або культурних потреб.

Для визначення мотивів вивчення іноземної мови важливо, насамперед, встановити, яким потребам може відповідати засвоєння іноземної мови.

Серед цих потреб можна виділити такі [6]:

- потреба комунікації в іншомовному середовищі;

- потреба комунікації у професійному середовищі;

- потреба в отриманні інформації;

- потреба у більш глибокому пізнанні дійсності;

- потреба в естетичному переживанні образного та понятійного багатства слова.

Важливим резервом розвитку самостійності і активності студентів $€$ урахування особливостей самої самостійної пізнавальної діяльності на заняттях з іноземної мови в залежності від обраної спеціальності. Врахування характерних особливостей пізнавальної діяльності сту- 
дентів конкретної спеціальності дозволяс виявити додаткові засоби формування у студентів активного і творчого підходу як до їх професійної підготовки, так і до вивчення іноземної мови.

В основі курсу іноземної мови лежать такі положення [6]:

- оволодіння іноземною мовою є одним із важливіших компонентів професійної підготовки сучасного фахівця;

- професійно орієнтований характер курсу іноземної мови, тому його завдання визначаються, в першу чергу, комунікативними та професійними потребами фахівців відповідного профілю;

- студент і викладач $є$ активними учасниками навчального процесу;

- студент є не тільки об'єктом навчання, але й його суб'єктом, і тому має право самостійно вирішувати ряд питань: включення до свого індивідуального плану факультативного курсу з іноземної мови, вибір матеріалів для самостійної роботи та ін.

У методичному плані активізація самостійної роботи пов'язана 3 культурою навчальної діяльності студентів, культурою їх розумової праці. Самостійна робота є особливою формою пізнавальної діяльності, ступінь удосконалення якої залежить від рівня культури розумової праці. Отже, для ефективності управління самостійною роботою студентів питання підвищення культури їх розумової праці має особливе значення. Рівень останньої обумовлює, значною мірою, успішність самостійної пізнавальної діяльності студентів, покращення якості їх підготовки у процесі самостійної роботи. 3 метою допомоги студентам оволодіти прийомами навчальної праці можливе впровадження спеціального курсу «Самостійна робота студентів».

Визначимо шляхи активізації самостійної пізнавальної діяльності студенів на заняттях з іноземної мови. Ними є [6]:

- розробка системи різнорівневих завдань для самостійної роботи, в основу якої закладено зміну характеру пізнавального завдання від репродуктивного до творчого;

- удосконалення змісту завдань i, водночас, збільшення частини самостійного пізнання студента у процесі його пізнавальної діяльності;

- мотиваційне зближення процесу виконання пізнавального завдання з самоосвітньою діяльністю;

- зменшення керування з боку викладача самостійною роботою студента. 


\section{4. Імплементація міжпредметних зв'язків}

Ретроспективний аналіз імплементації міжпредметних зв'язків свідчить, що ця проблема не є новим явищем у вітчизняній школі. Незважаючи на численні дослідження, застосування міжпредметних зв'язків у викладанні іноземної мови, багато питань все ж таки залишаються нерозглянутими. Зокрема у науково-педагогічній літературі зовсім не висвітлене розуміння ролі активного впровадження міжпредметних зв'язків у процес навчання іноземної мови студентів педагогічних спеціальностей.

Підхід до майбутньої освіти за допомогою декількох і часто інтегруючих дисциплін допомагає реалізувати цілісну мету міждисциплінарного та мультидисциплінарного підходу, створити цілісний футуристичний освітній досвід, який використовує різні режими свідомості та розуміння [13]. На думку Томаса Ломбардо (Thomas Lombardo), майбутня освіта може викладатися як курс інтегративних досліджень, або інтегративані студії в контексті майбутнього. Такий підхід до майбутньої освіти $€$ одночасно мультидисциплінарним та міждисциплінарним [13].

Міжнародне бюро освіти (IBE-ЮНЕСКО) визначає три основні типи сучасного підходу до інтеграції навчальних програм: мультидисциплінарний, міждисциплінарний та міждисциплінарний) [6].

Мультидисциплінарна навчальна програма (multidisciplinary curriculum) - це вивчення теми з точки зору більш ніж однієї дисципліни та вирішення проблеми з використанням іншого дисциплінарного підходу. Наприклад, вивчення теми «Вища освіта країни, мова якої вивчається» 3 дисципліни «Практичний курс англійської мови» можливий за умови вивчення курсу дисципліни «Університетські студії».

Інтердисииллінарна навчальна програма (interdisciplinary curriculum) - це розуміння теорій, що розрізають різні дисципліни та висвітлюють процес та значення, а не поєднання різних змістів дисципліни. Наприклад, сучасні педагогічні дослідження з предметів «Педагогіка», «Університетські студії» вимагають знань іноземної мови для опрацювання англомовної літератури.

Трансдисииллінарна навчальна програма (transdisciplinary curriculum) - це усунення меж між основними дисциплінами, інтегрування їх для побудови нового контексту реальних тем та ведення основного курсу [13]. 
В основному, міждисциплінарна навчальна програма розглядається як курс, що виходить 3 двох або більше навчальних дисциплін 3 використанням знань та методів роботи з однієї дисципліни та застосування їх до іншої дисципліни задля забезпечення більш широкого і глибокого засвоєння знань та набуття відповідних компетенцій. Щодо навчальних програм з окремих курсів, то вони містять у собі міжпредметні зв'язки, які включають у собі відомості з різних предметів, а саме завдання для активізації пізнавальної діяльності студентів.

Крім роботи з широким діапазоном знань, студенти, які займаються міждисциплінарними дослідженнями, працюють 3 декількома кафедрами, піддаючи їх різноманітним способам мислення та формуванню навичок спілкування.

Окремої уваги в країнах Європейського освітнього простору приділяють вивченню іноземних мов. В контексті міждисциплінарного підходу це означає, що змістові предмети викладаються та вивчаються мовою, яка це не $\epsilon$ рідною мовою студента. Інституції Єврокомісії, які відповідають за освітню і культурну політику, в рамках інноваційних освітніх програм прийняли спеціальний проект предметно-мовного інтегрованого навчання (Content and Language Integrated Learning (CLIL)), який полягає в навчанні іноземної мови, використовуючи змістовий потенціал інших навчальних дисциплін. Цей проект визначається як педагогічний підхід подвійного призначення: інтегроване вивчення другої мови разом із вивченням профільного предмету. Змістові предмети викладаються та вивчаються мовою, яка це не є рідною мовою студента. Цей методичний підхід широко застосовується в університетах Європи, що свідчить, про визнання західними науковцями і педагогами ефективності використання змісту різних навчальних дисциплін у навчанні іноземних мов.

Результати навчання, які можуть бути досягнуті за допомогою цього виду практики, залежать від кількості дисциплін, які беруть у ньому участь, а також виду знань, на які потрібно звернути увагу. У нашому дослідженні, проведеному на факультеті іноземної філології Миколаївського національного університету ім. В.О. Сухомлинського, студентам було запропоновано працювати над завданням, яке дозволило їм використати свої знання іноземної мови. Прикладом є завдання, які включають творчі роботи з метою активізації самостійної пізнавальної 
діяльності при вивченні дисциплін «Університетські студії», «Педагогіка», «Теорія і практика управління закладами освіти», які висвітлюють проблеми компаративістики, сучасних педагогічних досліджень в галузі педагогіки.

Такий інтегрований підхід дає позитивні результати. По-перше, студентам було надано можливість проявити та розвинути творчу уяву та глибокі знання з дисциплін, які вони вивчали. Не достатньо просто запам'ятовувати факти та формули в межах дисципліни; студентам пропонується творчо екстраполювати те, що вони вивчили по кожній дисципліні. По-друге, студентів проявили синтетичне мислення, долають надмірну фрагментацію, що міститься у типовій навчальній програмі. Окрім навчання та розвитку уяви, інтелектуальний синтез - $€$ проявом високого рівня пізнавальної майстерності, яка застосовуватиметься у майбутній професійній діяльності.

Актуальність проблеми міждисциплінарних зв'язків визначаться тим, що випускники закладів вищої освіти працевлаштовуються у різних галузях, численних компаніях, ніж було у минулому. Ці зміни у майбутньому кар'єрному шляху студента потребує того, щоб випускники університету володіти широким набором навичок та високим рівнем адаптивності. Здебільше вони здобуваються під час професійної підготовки фахівців 3 використанням міждисциплінарних (міжпредметних) підходів.

Значення терміну «інтегрувати» розглядали Інета Хелман та Ілізе Бражка (Ineta Helmane, Ilze Braska) [14]. Термін стосується об'єднання, адаптації, синтезу, включення, об'єднання та координації. Інтегрувати означає поєднувати дві чи більше речей, щоб стати більш ефективним. Інтегрований означає поєднуватись для утворення єдиного предмета, поєднуючи або координуючи окремі елементи, задля забезпечення гармонійного, взаємопов'язаного цілого організованого або структурованого таким чином, щоб складові одиниці функціонували спільно. Споріднені слова: повне, ціле, цілісне, притаманне, невіддільне, об'єднане. Слово «інтеграція» - це акт об'єднання в ціле. Синонімами слова «інтеграція» є консолідація, поєднання у цілісність. 3 інтеграційного аспекту важливо особливо вказати на внутрішню рівновагу, щоб у процесі викладання / навчання всі цілі та завдання спочатку окремих елементів, оскільки зміст самостійних шкільних предметів досягався і виконувався 
в навчальному процесі. Також важливим $є$ аспект цілісності особистості, як студент здобуває знання та вміння у процесі засвоєння навчального матеріалу та як вони будуть використовуватися та розвиватися, настанови для того, щоб повноцінно долучитися до навчального процесу. Ефективність інтегрованого викладання / навчання виправдана зв'язком навчання з життям (адже життя - це ціле), здобуттям єдності духовного розвитку особистості та розумінням узгодженості всередині знань. Інтегроване викладання / навчання чи процес викладання / навчання мають бути пов'язані з цілим, що передбачає не лише засвоєння навчального змісту, але й забезпечує «цілісний підхід до розвитку особистості сприяє інтелектуальному, емоційному та соціальному розвитку школяра у взаємозв'язку» [13]. Інтегроване викладання / навчання, пов'язане 3 цілим, забезпечує переважне втілення ідей викладання / навчання, оскільки під час засвоєння одного предмета, вивчаючи одне питання, студент отримає уявлення про зміст іншої дисципліни, яка також підлягає засвоєнню. Інтегрований процес навчання, який створює ціле породжує мотивацію у студента до навчання. Отже, важлива дія викладача, в результаті чого створюються умови, коли студент бачить цілісність змісту навчання, а не викладач вказує на зв'язки, які слід бачити. Усвідомлення мотиву в інтегрованому навчанні - це внутрішня рушійна сила, суб'єктивна складова, індивідуальна і для всіх різна [15]. Інтегроване навчання може бути умовою забезпечення навчання, що передбачає структуровану роботу з чіткою концепцією, методами та принципами, поєднуючи декілька освітніх парадигм таким чином, що дає можливість кожному учневі навчатися у власному стилі та орієнтирах в офіційно визнаному навчанні середовище.

Префікс «мульті» описується Інетою Хелман та Ілізе Бражка як поєднання форми, що означає «багато, багато, багато, багато разів, більше одного, більше двох» і використовується при формуванні складних слів (словник.com) [14]. На практиці це може бути пов'язано 3 кожним випадком, коли одночасно вивчається більше ніж один предмет. Мультидисциплінарні підходи зосереджуються насамперед на дисциплінах. Викладачі, які застосовують такий підхід, організовують стандарти $з$ дисциплін навколо теми.

Слово «інтер» використовується для утворення прикметників, що означають «між або серед згаданих людей, речей або місць» (Кемб- 
риджський словник). Слово «міждисциплінарний характер» поєднує або включає дві або більше навчальні дисципліни або поєднує дві або більше професій, технологій, кафедр тощо, як у бізнесі, так і галузі [14]. Міжпредметні дисципліни - це те, що охоплює більш однієї галузі вивчення; inter - (латина) означає «між», і дисциплінарне, що $є$ від латинської «дисципліна) і означає викладання чи знання. При міждисциплінарному підході викладачі розробляють навчальну програму навколо загального навчання з різних дисциплін Вони поєднують спільне навчання, закладене в дисциплінах, щоб підкреслити міждисциплінарні навички та концепції. Дисципліни є ідентифікованими, але вони набувають меншої важливості, ніж у мультидисциплінарному підході [14].

Зарубіжні дослідники приходять до висновку [14]:

- метою інтегрованого навчання $є$ цілісний розвиток особистості студента шляхом єдності навчання з реальним життям;

- усі підходи до інтегрованої навчальної програми виявляються більш ефективними для навчання студентів, ніж традиційний підхід на основі однієї дисципліни;

- основні відмінності між підходами інтеграції навчальних програм полягають у розумінні стратегій, взаємозв'язків та складності контекстів;

- ефективна реалізація цілей освіти можлива за умови розуміння типів інтеграції, а також способів планування та співпраці;

- у контексті нових вимог до освіти (розвиток компетенцій) - трансдисциплінарний підхід можна розглядати як найпродуктивніший вид інтеграції.

Отже, основна мета професійної підготовки фахівців полягає у формуванні знань студентів про певну дисципліну, яка допомагає майбутнім фахівцям аналізувати інформацію та застосовувати ії у реальному житті. Розуміння студентами зв'язку між різними предметами покращує розуміння студентів дисциплін та робить навчальний процес більш продуктивним і приємним.

\section{5. Висновки і пропозиції}

Отже, наукова проблема активізації самостійної пізнавальної діяльності студентів на заняттях з іноземної мови $є$ ефективним інструментом забезпечення якості освіти. 
Ефективність самостійної пізнавальної діяльності студентів зумовлена їі організацією. Організація - динамічний процес, в кому є діяльність студента, керування викладача, де створюються відповідні взаємовідношення. В основі організації ефективного навчального процесу повинен бути принцип активності і самостійності в навчанні студента.

Загальноорганізаційні вміння студентів слід розвивати. Ефективність організації пізнавальної діяльності студентів визначається рівнем особистої готовності студента до оволодіння знаннями. Потрібна диференціація рівнів особистої готовності студентів до оволодіння знаннями та врахування дидактичних умов і відношень, які формуються між викладачем і студентом та індивідуальних здібностей і інтересів студентів.

Комплексний характер організаційних заходів щодо організації самостійної пізнавальної діяльності студентів передбачає визначення основних за своїм розвиваючим значенням прийомів. До них можна віднести такі:

- використання викладачем методичних прийомів щодо організації самостійної роботи студентів на заняттях з іноземної мови;

- організація ситуацій колективного вирішення завдань, дискусія та обговорення результатів;

- розробка критеріїв ефективності організації самостійної пізнавальної діяльності студентів на заняттях з іноземної мови.

Міждисциплінарні дослідження є оптимальним варіантом для розвитку творчого мислення студентів, що дозволяють їм досліджувати та встановлювати зв'язки між найрізноманітнішими ідеями, методами та способами мислення. Вивчення двох або більше пов'язаних між собою предметів є корисним для кращого розуміння предметів, оскільки вони дозволяють студентам застосовувати знання, отримані в одній галузі, для поліпшення їхнього розуміння предмету в іншому.

\section{Список літератури:}

1. Державна національна програма «Освіта» («Україна XXI століття»). 1993. URL: http://zakon1.rada.gov.ua/cgi-bin/laws/main.cgi

2. Дебич М.А. Теоретичні засади інтернаціоналізації вищої освіти: міжнародний досвід : монографія. Ніжин : ПП Лисенко, 2019. 408 с.

3. Енциклопедія освіти / [голов. редак. В.Г. Кремень]. Київ : Юрінком Інтер, 2008. $1040 \mathrm{c}$. 
4. Закон України “Про вищу освіту”. 2014. URL: http://zakon4.rada.gov.ua/ laws/show/1556-18

5. Заскалєта С., Буглай Н. Застосування міжпредметних зв'язків для забезпечення якості вищої освіти. Неперервна професійна освіта: теорія і практика. 2020. Вип. 3. С. 102-108.

6. Заскалєта С.Г. Організація самостійної пізнавальної діяльності студентів сільськогосподарського інституту (за матеріалами вивчення іноземних мов) : автореферат дисс. кандидата пед. наук : 13.00.04 / ІПППО АПН України. Київ, 2000. 20 с.

7. Заскалєта С., Щербакова О. Застосування принципів міжпредметних звязків у вищій школі: зарубіжний досвід. Освітологічний дискурс. 2020. Вип. 2(29). С. 121-131.

8. Кляп Маріанна. Інноваційні методи навчання у ВНЗ як інструмент інтернаціоналізації вищої освіти України. Вища освіта України. 2015. № 4. С. 45-53.

9. Кремень В.Г. Філософія національної ідеї. Людина. Освіта. Соціум. Київ : Грамота, 2007. 576 с.

10. Огнев’юк В.О. Філософія освіти в структурі наукових досліджень феномену освіти. Шлях освіти. 2009. № 2. С. 2-6.

11. "Про вищу освіту”: Закон України. 2014. URL: http://zakon4.rada.gov.ua/ laws/show/1556-18

12. Про Національну доктрину розвитку освіти. 2002. URL: https://zakon.rada.gov.ua/laws/show/347/2002\#Text

13. Multidisciplinary and Interdisciplinary Approaches to Futures Education by Thomas Lombardo. 2010. Retrieved from: https://www.academia.edu/1160929/ Multidisciplinary_and_Interdisciplinary_Approaches_to_Futures_Education

14. What is developing integrated or interdisciplinary of multidisciplinary or transdisciplinary education in school? by Ineta Helmane, Ilze Braska. 2017. Retrieved from: https://www.researchgate.net/publication/332579341_What_is Developing_Integrated_or_Interdisciplinary_or_Multidisciplinary_or_Transdisciplinary_Education_in_School

15. Multidisciplinary and Interdisciplinary Approaches to Futures Education by Thomas Lombardo. 2010. Retrieved from: https://www.academia.edu/1160929/ Multidisciplinary_and_Interdisciplinary_Approaches_to_Futures_Education

16. Multidisciplinary teaching: an approach to active learningby Dr Saad Odeh. 2018. Retrieved from: https://learningandteaching-navitas.com/multidisciplinaryteaching-approach-active-learning/

\section{References:}

1.Derzhavna natsionalna prohrama «Osvita» («Ukraina XXI stolittia») [State National Program «Education» («Ukraine of the XXI Century»)] (1993). URL: http://zakon1.rada.gov.ua/cgi-bin/laws/main.cgi

2. Debych M.A. (2019) Teoretychni zasady internatsionalizatsii vyshchoi osvity: mizhnarodnyi dosvid: monohrafiia [Theoretical principles of internationalization of higher education: international experience]. Nizhyn: PP Lysenko, 408 p. 
3. Entsyklopediia osvity [Encyclopedia of Education] [holov. redak. V.H. Kremen] (2008). Kyiv: Yurinkom Inter, 1040 p.

4.Zakon Ukrainy "Pro vyshchu osvitu" [Law of Ukraine "On Higher Education"] (2014). URL: http://zakon4.rada.gov.ua/laws/show/1556-18

5.Zaskalieta S., Buhlai N. (2020) Zastosuvannia mizhpredmetnykh zviazkiv dlia zabezpechennia yakosti vyshchoi osvity [Application of interdisciplinary links to ensure the quality of higher education]. Neperervna profesiina osvita: teoriia $i$ praktyka, vol. 3, pp. 102-108.

6. Zaskalieta S.H. (2000) Orhanizatsiia samostiinoi piznavalnoi diialnosti studentiv silskohospodarskoho instytutu (za materialamy vyvchennia inozemnykh mov) [Organization of independent cognitive activity of students of agricultural institute (foreign languages clusses)]: avtoreferat dyss. kandydata ped. nauk: 13.00.04 / IPPPO APN Ukrainy. Kyiv, 20 p.

7.Zaskalieta S., Shcherbakova O. (2020) Zastosuvannia pryntsypiv mizhpredmetnykh zviazkiv u vyshchii shkoli: zarubizhnyi dosvid [Application of the principles of interdisciplinary links in higher education: foreign experience]. Osvitolohichnyi dyskurs, vol. 2(29), pp. 121-131.

8. Kliap Marianna (2015) Inovatsiini metody navchannia u VNZ yak instrument internatsionalizatsii vyshchoi osvity Ukrainy [Innovative teaching methods in higher education as a tool for internationalization of higher education in Ukraine]. Vyshcha osvita Ukrainy, no. 4, pp. 45-53.

9. Kremen V.H. (2007) Filosofiia natsionalnoi idei. Liudyna. Osvita. Sotsium [Philosophy of the national idea. Man. Education. Society]. Kyiv: Hramota, 576 p.

10. Ohneviuk V.O. (2009) Filosofiia osvity v strukturi naukovykh doslidzhen fenomenu osvity [Philosophy of education in the structure of scientific research of the phenomenon of education]. Shliakh osvity, no. 2, pp. 2-6.

11. "Pro vyshchu osvitu": Zakon Ukrainy [Law of Ukraine «On higher education»] (2014). URL: http://zakon4.rada.gov.ua/laws/show/1556-18

12. Pro Natsionalnu doktrynu rozvytku osvity. [On the National Doctrine of Education Development] (2002). URL: https://zakon.rada.gov.ua/laws/show/ 347/2002\#Text

13. Multidisciplinary and Interdisciplinary Approaches to Futures Education by Thomas Lombardo. Retrieved from: https://www.academia.edu/1160929/ Multidisciplinary_and_Interdisciplinary_Approaches_to_Futures_Education

14. What is developing integrated or interdisciplinary of multidisciplinary or transdisciplinary education in school? by Ineta Helmane, Ilze Braska. Retrieved from: https://www.researchgate.net/publication/332579341_What_is_Developing Integrated_or_Interdisciplinary_or_Multidisciplinary_or_Transdisciplinary_ Education in School

15. Multidisciplinary and Interdisciplinary Approaches to Futures Education by Thomas Lombardo. Retrieved from: https://www.academia.edu/1160929/ Multidisciplinary_and_Interdisciplinary_Approaches_to_Futures_Education

16. Multidisciplinary teaching: an approach to active learningby Dr Saad Odeh . Sep 24, 2018. Retrieved from: https://learningandteaching-navitas.com/multidisciplinary-teaching-approach-active-learning/ 